\title{
A SYSTEMATIC REVIEW: NON-INVASIVE TREATMENT TO REDUCE LOW BACK PAIN AMONG TREATMENT ACUPUNTURE, MASSAGE, SPINAL MANIPULATION, YOGA, AND TAI CHI
}

\author{
Cecep Eli Kosasih, Tetti Solehati, Agus Cakrahayat \\ Faculty of Nursing, Universitas Padjadjaran, Bandung, Indonesia \\ Correspondence: ek_cecep@yahoo.co.id
}

\begin{abstract}
Low back pain (LBP) is one of the many spinal cord-positioning conditions commonly experienced by adults. Age factors affect the seriousness of trauma to the spine as in patients with osteoporosis under unusual conditions caused by radiculopathy or spinal stenosis, fracture, tumor or infection. This article aimed to identify the most effective non-invasive treatment in treating pain in Low Back Pain (LBP). Cirtical review was used in making this article. Articles were collected through Medline, Google Scholar, Science Direct, Pubmed databases using the keywords: treatment, non-invasive, Low Back Pain from the quantitative studies. The selected articles were those that met the criteria based on PICO, published in the 2010-2017, and used English language. Articles were then evaluated using critical appraisal and PRISMA guides. Based on the evaluation, there are 6 (six) articles that match the purpose and criteria of review. From the literature search results found ways to reduce pain through non-invasive treatment such as Acupunture, Massage, Spinal Manipulation and Yoga can reduce LBP pain. The result of the literature that the most effective method of reducing pain is spinal manipulation where the effect of reducing pain can be maintained for a long time and is more applicable because without the use of aids, nevertheless treatment combined with other treatments and done on an ongoing basis will better results.
\end{abstract}

Keywords: Low Back Pain, Non-invasive Treatment

\section{INTRODUCTION}

Low back pain (LBP) is one of the many spinal cord positioning disorder often experienced by adults, although it often resolves with minimal treatment but there are also more severe conditions requiring treatment from the spine specialist. In most patients receiving basic services and symptoms may not be specified so that the patient is classified as non-specific LBP (Henschke, et al., 2009). The age factor affects the seriousness of trauma to the spine as in patients with osteoporosis under unusual conditions caused by radiculopathy or spinal stenosis, fracture, tumor or infection (Qasem, McLean, Forciea, \& Wilth, 2017).

Treatment is given to reduce pain in non-specific LBP. Pain level feel by the patient is different and also patient has anxiety. Most cases will heal by themselves, but $31 \%$ of people with LBP can not fully heal up to 6 months. Acute LBP is diagnosed if 6 to 12 weeks experience pain between costal angles and gluteal folds 
that radiate down on one or two lower limbs (sciatica). The goal of treatment at LBP is to reduce pain, improve function, reduce time ineffectiveness in work and improve learning strategy (Brian, 2012).

According to Guidelines of the American College of Physician and the American Pain Societies recommend that patients with non-specific LBP should use NSAIDS and will extend the healing period and return to normal activities. Some patients are more interested in non-pharamacological therapies including Spinal Manipulation (Michael, Mitchell, Ronald, Joel, \& Doug, 2015). For acute and chronic LBP based CPGs on non invasive management of LBP and national CPGs published since 2016 in United State, National Intitute for Care Excellent (NICE) (De Campos, 2017) and Denmark National Guidline (Stochkendahl, et al., 2017 ) recommend a teraphy manual that includes SM, Mobilization like Massage. The CPG of the American College of Physicians (ACP) (Qasem, McLean, Forciea, \& Wilth, 2017), rebranded non-pharmacological treatments for acute and chronic LBP such as (Superficial Heat, Massage, Acupuncture and SM) prior to pharmacological treatment.

In overcoming the pain in Low Back Pain (LBP) there are various non invasive treatments that will support healing from the many treatments include Massage, Spinal Manipulation, and Yoga. Based on the problems mentioned earlier, it is important to search the literature as a first step to identify the most effective noninvasive treatment for treating pain in Low Back Pain (LBP). Therefore, the authors want to know which treatment is most effective and get healing in a long time through literature review of non infasive treatments in reducing LBP pain.

\section{METHODS}

This systematic review aimed to identify the most effective non-invasive treatment in treating pain in Low Back Pain (LBP). Articles were collected through Medline, Google Scholar, Science Direct, Pubmed databases using the keywords: treatment, non-invasive, Low Back Pain from the quantitative studies. The selected articles were those that met the criteria based on PICO, published in the last 10 years and using 
English language. The inclusion criteria that should included the most effective and aplicable methods of time and tools to reduce pain in LBP, Articles are then evaluated using critical appraisal and PRISMA guidance. Based on the evaluation, there are 6 (six) articles reviewed. The PRISMA diagram for the determination of literature is as follows:

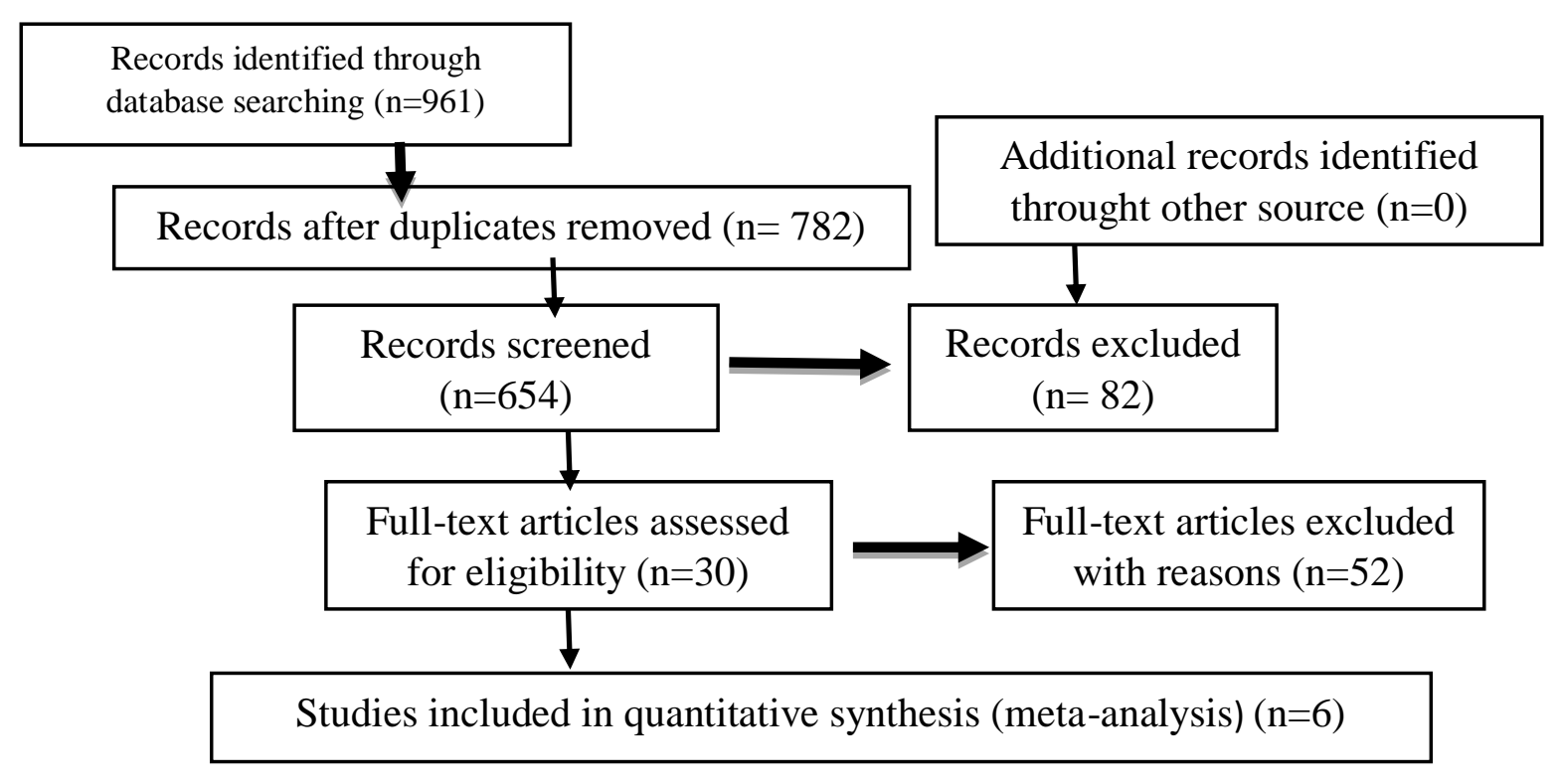

Figure 1 Searching Methods of Systemic Review

\section{RESULTS}

Table 1 Summary of The Results

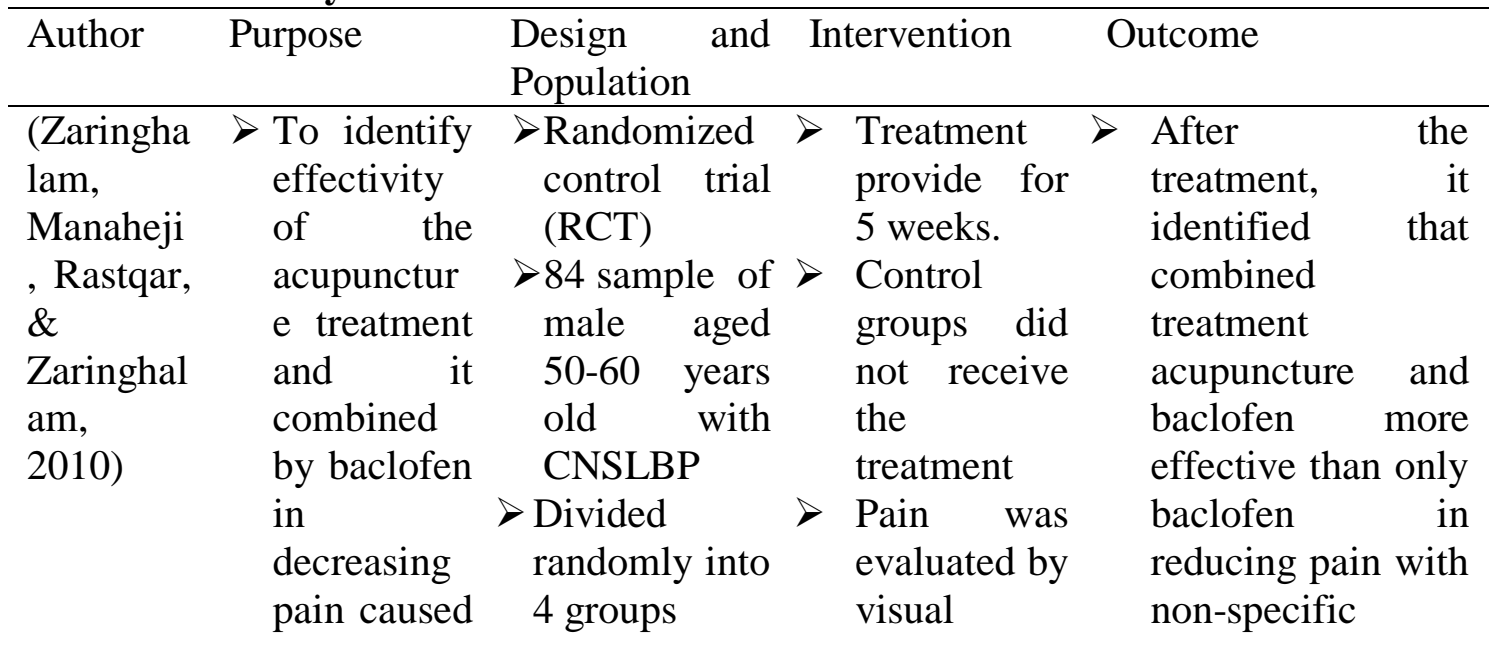




\begin{tabular}{|c|c|c|c|c|}
\hline & by LBP & $\begin{array}{l}\text { - } \text { Control (C) } \\
\text { - Acupunture } \\
\text { (AC) } \\
\text { - Baclofen } \\
\text { (BA) } \\
\text { - Baclofen + } \\
\text { Acupuntur } \\
\text { (BA+AC) }\end{array}$ & $\begin{array}{l}\text { analogue } \\
\text { scale (VAS) } \\
\text { and self- } \\
\text { reported } \\
\text { pain } \\
\text { disability } \\
\text { with the } \\
\text { Roland- } \\
\text { Morris } \\
\text { Disability } \\
\text { Questionnai } \\
\text { re (RDQ) } \\
\text { Accupuntur } \\
\text { e } \\
\text { recorded } \\
\text { according to } \\
\text { STRICTA } \\
\text { standard } \\
\text { (standard } \\
\text { for reporting } \\
\text { intervention } \\
\text { in clinical } \\
\text { trial } \\
\text { acupuncture } \\
\text { Baclofen } \\
\text { was } \\
\text { provided } \\
\text { orally for } 30 \\
\text { mg/days }\end{array}$ & chronic LBP \\
\hline $\begin{array}{l}\text { (Hasega } \\
\text { wa, } \\
\text { Baptista, } \\
\text { de Souza, } \\
\text { Yoshizu } \\
\text { mi, \& } \\
\text { Natour, } \\
\text { 2014) }\end{array}$ & $\begin{array}{l}\text { To identify } \\
\text { effectivene } \\
\text { ss of } \\
\text { Yamato's } \\
\text { acupunctur } \\
e \quad \text { in } \\
\text { reducing } \\
\text { pain, } \\
\text { reducing } \\
\text { drug } \\
\text { consumed, } \\
\text { and } \\
\text { increasekan } \\
\text { quality of }\end{array}$ & 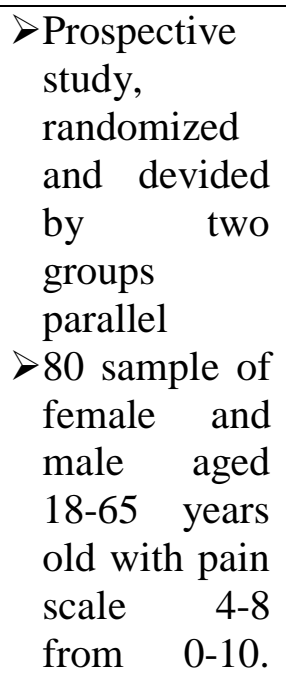 & $\begin{array}{l}\text { Yamato's } \\
\text { acupunture } \\
\text { treatment and } \\
\text { other group } \\
\text { was placebo } \\
\text { Acupunture }\end{array}$ & $\begin{array}{l}\text { Yamato's } \\
\text { scalp acupunture } \\
\text { more effective than } \\
\text { placebo treatment } \\
\text { that reduced pain } \\
\text { and able to increase } \\
\text { fuctional status and } \\
\text { Quality of life of } \\
\text { the pasien with } \\
\text { ANLBP }\end{array}$ \\
\hline
\end{tabular}




\begin{tabular}{|c|c|c|c|c|c|}
\hline & $\begin{array}{l}\text { life pasien } \\
\text { ANLBP }\end{array}$ & $\begin{array}{l}\text { Devided into } \\
\text { two groups } \\
\text { randomly, } \\
\text { the group } \\
\text { received the } \\
\text { intervention } \\
\text { (IG) and } \\
\text { other } \\
\text { intervention } \\
\text { (SG) }\end{array}$ & & & \\
\hline $\begin{array}{l}\text { Yoon, } \\
\text { Yu, Lee, } \\
\text { Kwak, \& } \\
\text { Kim, } \\
\text { 2012) }\end{array}$ & $\begin{array}{l}\text { Application } \\
\text { of deep } \\
\text { cross-friction } \\
\text { massage by } \\
\text { using HT-bar } \\
>\text { To identify } \\
\text { it's } \\
\text { effectiveness }\end{array}$ & $\begin{array}{l}-22 \text { samples } \\
\text { devided into } \\
\text { two groups } \\
\text { randomly } \\
- \text { Roptrotherap } \\
\text { y }(\mathrm{n}=11) \\
- \text { transcutaneo } \\
\text { us electrical } \\
\text { nerve } \\
\text { stimulation } \\
\text { (TENS) } \\
(\mathrm{n}=11)\end{array}$ & $\begin{array}{l}\text { The results of } \\
\text { treatment was } \\
\text { evaluated by } \\
\text { Pain } \\
\text { Numeric } \\
\text { Rating Scale } \\
\text { (PNRS) } \\
>\text { Oswestry } \\
\text { Disability } \\
\text { Index (ODI) } \\
\text { the Roland } \\
\text { Morris } \\
\text { Disability } \\
\text { Questionnai } \\
\text { re (RMDQ) } \\
\text { Treatment } \\
\text { provided for } \\
20 \text { minutes } \\
\text { and } 6 \text { times } \\
\text { in two } \\
\text { weeks. } 3 \\
\text { times per } \\
\text { weeks }\end{array}$ & $>$ & 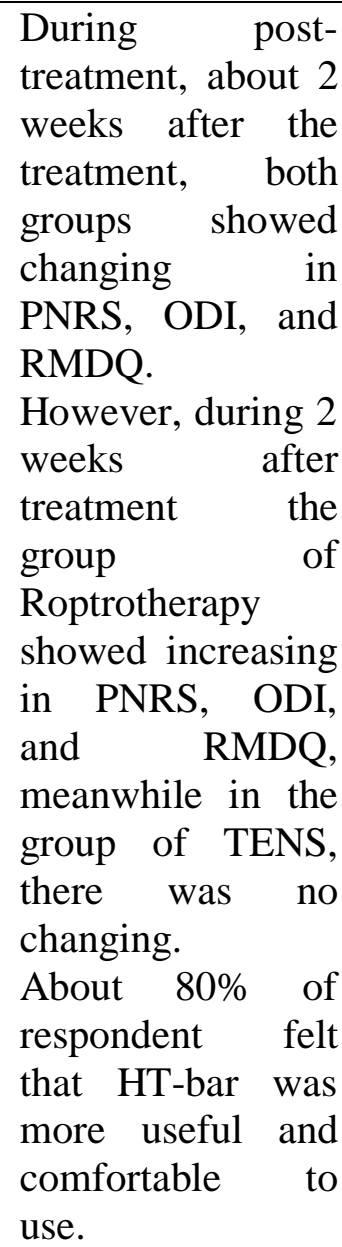 \\
\hline $\begin{array}{l}\text { (Michael } \\
\text { Schneide } \\
\text { r, } \\
\text { Mitchell } \\
\text { Haas, } \\
\text { Ronald } \\
\text { Glick, } \\
\text { Joel }\end{array}$ & $\begin{array}{l}\text { This study } \\
\text { compared } \\
\text { the } \\
\text { effectivene } \\
\text { ss of } \\
\text { manual- } \\
\text { thrust } \\
\text { manipulatio }\end{array}$ & 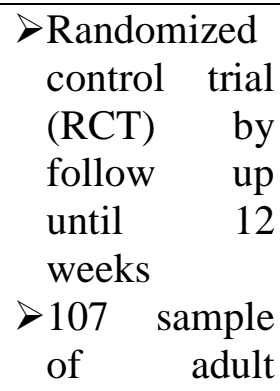 & $\begin{array}{l}\text { (MTM): } \\
\text { providing } \\
\text { high-velocity } \\
\text { low- } \\
\text { amplitude } \\
\text { thrust } \\
\text { manipulation } \\
\text { in posture }\end{array}$ & $>$ & $\begin{array}{l}\text { MTM reducing } \\
\text { pain in } \\
\text { a larger short-term } \\
\text { reduction of } \\
\text { reported disability } \\
\text { compared to UMC } \\
\text { or MAM }\end{array}$ \\
\hline
\end{tabular}




\begin{tabular}{|c|c|c|c|c|}
\hline $\begin{array}{l}\text { Stevans, } \\
2015)\end{array}$ & $\begin{array}{l}\text { n (MTM) } \\
\text { and } \\
\text { mechanical } \\
\text {-assisted } \\
\text { manipulatio } \\
\text { n (MAM) } \\
\text { Both types } \\
\text { manipulate } \\
\text { d by usual } \\
\text { medical } \\
\text { care } \\
\text { (UMC), for } \\
\text { treatment } \\
\text { of acute } \\
\text { and sub- } \\
\text { acute LBP. }\end{array}$ & $\begin{array}{l}\text { devided into } \\
3 \text { groups } \\
-\quad \text { MTM } \\
-\quad \text { MAM } \\
-\quad \text { UMC }\end{array}$ & $\begin{array}{l}\text { sideways } \\
\text { position } \\
\text { (MAM): } \\
\text { Participants } \\
\text { was provided } \\
\text { manipulation } \\
\text { in prone } \\
\text { position } \\
\text { (UMC): } \\
\text { participans } \\
\text { was seen by } \\
\text { medical } \\
\text { doctor, } \\
\text { certified } \\
\text { board in } \\
\text { physical and } \\
\text { rehabilitation } \\
\text { treatment }\end{array}$ & \\
\hline $\begin{array}{l}\text { (Senna \& } \\
\text { MacHaly } \\
\text {, 2011) }\end{array}$ & $\begin{array}{l}\text { To identified } \\
\text { effectiveness } \\
\text { of spinal } \\
\text { manipulation } \\
\text { therapy } \\
\text { (SMT), to } \\
\text { manage the } \\
\text { chronic non- } \\
\text { specific low } \\
\text { back pain } \\
\text { (LBP) and to } \\
\text { determine } \\
\text { effectiveness } \\
\text { maintenance } \\
\text { of SMT in } \\
\text { reducing } \\
\text { long term } \\
\text { pain and } \\
\text { level of } \\
\text { disability } \\
\text { related LBP } \\
\text { condition } \\
\text { after early } \\
\text { phase of } \\
\text { caring. }\end{array}$ & $\begin{array}{l}\text { A } \\
\text { prospective } \\
\text { single } \\
\text { blinded } \\
\text { placebo } \\
\text { controlled } \\
\text { study was } \\
\text { conducted. } \\
\text { Objective. } \\
60 \text { patient } \\
\text { with chronic } \\
\text { LBP that } \\
\text { devided into } \\
3 \text { groups }\end{array}$ & $\begin{array}{l}\text { Every group } \\
\text { - Received } 12 \\
\text { treatment of } \\
\text { SMT placebo } \\
\text { for } 1 \text { month } \\
\text { - Received } 12 \\
\text { treatment of } \\
\text { SMT for } 1 \\
\text { month } \\
\text { - received } 12 \\
\text { treatment of } \\
\text { SMT for } 1 \\
\text { bulan and it } \\
\text { continued } \\
\text { every } 2 \text { weeks } \\
\text { until } 9 \\
\text { months. } \\
\text { - Measured of } \\
\text { pain score, } \\
\text { disability, and } \\
\text { general health } \\
\text { status and } \\
\text { patient } \\
\text { satisfaction }\end{array}$ & $\begin{array}{l}\text { Patient in } \\
\text { group } 2 \text { has pain } \\
\text { score lowerthan the } \\
\text { first group but } \\
\text { group } 3 \text { has lower } \\
\text { result and } \\
\text { increasing recovery } \\
\text { in long term of time } \\
\text { SMT was } \\
\text { effective to cure } \\
\text { LBP and to get } \\
\text { long term benefit, it } \\
\text { suggested to } \\
\text { conduct continuity } \\
\text { treatmement }\end{array}$ \\
\hline (Hall, & $>$ To identify & Randomized & $>$ Treatment of & Group \\
\hline
\end{tabular}




\begin{tabular}{|c|c|c|c|c|}
\hline $\begin{array}{l}\text { Maher, } \\
\text { Lam, } \\
\text { Ferreira, } \\
\text { \& } \\
\text { Latimer, } \\
\text { 2011) }\end{array}$ & $\begin{array}{l}\text { effectivene } \\
\text { ss tai chi } \\
\text { treatment } \\
\text { in reducing } \\
\text { of pain and } \\
\text { disability } \\
\text { due to } \\
\text { LBP. }\end{array}$ & $\begin{array}{l}\text { control trial } \\
\text { (RCT) } \\
\text { 160 samples } \\
\text { devided into } \\
\text { two groups } \\
\text { randomly. } \\
\text { The group } \\
\text { received tai } \\
\text { chi treatment } \\
\text { (n = 80) and } \\
\text { the group } \\
\text { received } \\
\text { placebo } \\
\text { treatment } \\
\text { (n=80) }\end{array}$ & $\begin{array}{l}\text { tai Chi for } 40 \\
\text { minutes by } \\
\text { certified } \\
\text { instructure } \\
\text { and got } \\
\text { treatment all } \\
18 \text { session for } \\
10 \text { weeks, } \\
\text { twice sessin } \\
\text { in in a week. } \\
\text { For control } \\
\text { group was } \\
\text { suggested to } \\
\text { do other } \\
\text { fitness for } 10 \\
\text { weeks also } \\
\text { Using } \\
\text { Roland- } \\
\text { Morris } \\
\text { Disability } \\
\text { Questionnaire } \\
\text { scale }\end{array}$ & $\begin{array}{l}\text { received tai chi } \\
\text { intervention able to } \\
\text { decrease symptom } \\
\text { pain and pain } \\
\text { related with } \\
\text { disability in the } \\
\text { intervention group. } \\
\text { Tai chi } \\
\text { exercise reduced } \\
\text { uncomfortable due } \\
\text { to symptom of } 1.7 \\
\text { points on a 0-10 } \\
\text { scale, reducing pain } \\
\text { intensity } 1.3 \text { points } \\
\text { on a } 0-10 \text { scale, } \\
\text { and increasing } \\
\text { ability } 2.6 \text { points on } \\
\text { the 0-24 Roland- } \\
\text { Morris Disability } \\
\text { Questionnaire } \\
\text { scale. The followup } \\
\text { rate was >90\% for } \\
\text { all outcomes. This } \\
\text { study was able to } \\
\text { give a good effect. }\end{array}$ \\
\hline
\end{tabular}

\section{DISCUSSION}

Based on the results of systematic review, known several methods that can be providing to reduce pain in LBP non invasive as follows:

\section{Acupunture}

Acupuncture is defined as the use of needles in various places throughout the body to prevent, treat and maintain health. In 2003 WHO issued a report on the effectiveness of acupunture in overcoming the disease one of which LBP is supported by clinical trials in 28 diseases (WHO, 2002). In a study conducted by (Zaringhalam et al. 2010) with a sample of 84 male-aged samples 50-60 years with non-specific Low back pain chronicle divided into 4 groups with the division of Control (C), Acupunture (AC), Baclofen $(\mathrm{BA})$ and Baclofen + Acupuntur $(\mathrm{BA}+\mathrm{AC})$. after 5 weeks of treatment, the results in acupunture + baclofen and acupunture group increased significantly more 
results in reducing pain than baclofen alone, seen from the assessment of pain intensity score / Visual analog Scale (VAS) and Roland-Morris Disability (RDQ), with group acupunture + baclofen (40.1), group acupunture (47), baclofen group (61.9) and group control (64.3).

Another thing was reported in the study by (Hasegawa et al., 2014) using a sample of 80 men and women with non-specific low back pain acute (ANLB) in this study. The patients were only told to receive treament acupunture but the researchers gave different treatments in two groups. Where the first group is Yamato's acupunture treatment and the second group of placebo Acupunture is randomly selected then the patient gets 5 acupunture sessions. Patients will be assessed on days 3, 7, 14 and 28 using VAS and RM, qualiti of life (SF-36). The final results obtained by treatment using Yamamoto's nwe scalp treatment were more effective than other placebo acupunture treadment in improving functional status and quality of life of ANLB patients. The study was conducted by a member of the Brazilian Medical ASSOciation of Acupuncture and has been acupuncture practice for 15 years.

\section{Massage}

Treatment of massage in reducing LBP pain has been done by (Yoon et al., 2012). In his study were 22 samples consisting of 9 men and 13 women with age 51.6- 67 with Cronic non-specific low back pain (CNLB) treatment as much 20 minutes a day, 5 days a week and in two weeks) sample is divided into two groups: A roptrotheraphy $(\mathrm{n}=12)$ gets deep cross-friction massage with HT and Transcutaneous Electrical Nerve Stimulation (TENS) group $(\mathrm{n}=10)$ got the TENS. The assessment uses pain rating numeric scal (PNRS), oswestry disabilty index (ODI) and the Roland Morris Disability Questionnaire (RMDQ). Where the results of both groups showed a significant increase, but in the group who get deep cross-friction massage with HTbar more influential and more comfortable felt by the patient. In this study researchers used a T-bar tool that consists of metal in thoracolumbar regions (T6-L3). 


\section{Spinal Manipulation}

Some literature and according to national clinical practice guidline (CPGs) in the treatment of LBP should be considered for use of SM. to determine the correct therapy for the right patient should compare the effectiveness, risk and cost of doing a treadment (Notley \& Hopayin, 2014). Assessing the effectiveness of Spinal Manipulation (SM) as one of the treadments in overcoming LBP pain that has been mostly from research more centered on the temporary effects of SM. But did not close the possibility to get the effect in a long time. The research is conducted by (Senna \& MacHaly, 2011) to see the possibility of results in a long time. In the study there were 60 samples with CNLB selected at random. The overall sample was divided into three groups. The first group was given 12 treatments of several SM actions for one month. The second group was given a month-long sustained treatments and no 9-month tratment and a third treatment group was administered for a month and continued to be treated biweekly for up to 9 months. Assessment of pain is done at one month, 4 months, 7 months and 10 months. Results obtained by the third group there was a decrease of pain level between the two groups before the inability of the patient to return to pre treatment.

Spinal manipulation itself there are several kinds to see the effectiveness of several $\mathrm{BC}$ have done research to compare some methods of $\mathrm{BC}$ by (in this case the researchers compare the effectiveness of Manual-thrust manipulation (MTM) with mechanical-as- maned manipulation (MAM) and manipulation versus usual medical care (UMC). This study used 107 samples with LBP divided into three groups with different treatments for 12 weeks. The result is measured using the outcome measure included the Oswetry LBP disabilty index (0-100 scale) and the numerical pain rating (0-10 scale). Treatment is performed twice a week twice in 4 weeks. The results will be seen at week 4, month 3 and month 6 . Results were obtained for pain reduction (94: 76\%) on MTM treatments, compared to MAM (69; 47\%) and UMC (56-41\%). self-reported disability: (76; 50\%) on MTM treatments, compared to MAM $(50 ; 16 \%)$ and UMC $(48 ; 47 \%)$. Treatment of MTM is preferred for reducing self-reported disability and LBP pain. 


\section{Yoga}

Yoga is one sport that can overcome pain in LBP but the extent to which effectiveness is still a concern. One study of efficacy and eficiensy yoga in overcoming pain. One of the studies that tried to prove it was done by (Williams et al., 2009) with the overall subjects of the study $n=90$, divided into two groups with the first group received treatment $(n=43)$ and the second group as the control group $(\mathrm{n}=47)$. Participants followed this study for 24 weeks. The results will be seen at mid-time 12 (midway) and 24 and 48 weeks for 6 months. Assessment using Oswestry Disability Quesioner. Yoga results have increased dissability, reduced pain intensity and depression in the use of yoga as a treatment to overcome problems in LBP have additional value to reduce the anxiety level of patients after doing yoga with affordable cost.

Increased costs for LBP treatment into consideration in choosing treatment for patients. For own expenses required a separate sitematical review in comparing the costs to be incurred by the patient. a sitematical review conducted by (Lin, Haas, Maher, MacHado, \& Van Tulder, 2011) mentions for patients who do not experience an increase in LBP pain conditions Spinal Manipulation treatment has the most minimum cost. Personality for patients with no improved health conditions suggests incorporating intradinlinary rehabilitation such as exercise, acupunture, massage, spinal manipulation, yoga, cognitive behavior, relaxation for acute and chronic LBP

\section{Tai chi}

Tai chi derived from China is a mild sport and combines balance, strengthening, stretching, and body awareness, and is commonly practiced throughout Asia for general health and certain conditions. One study identified the effectiveness of tai chi treatment in reducing pain and disability because the LBP performed by (Hall et al., 2011) in 160 samples was divided into two groups randomly. Group receiving tai chi treatment $(n=80)$ and group receiving placebo treatment $(n=80)$. Obtained Group results that receive thai ci intervention are able to relieve pain due to symptoms and 
pain associated with the inability of the control intervention group. Acquired results Tai chi reduces feelings of discomfort due to symptoms of 1.7 points on a $0-10$ scale, reduces pain intensity 1.3 points on a $0-10$ scale, and increases the ability of 2.6 points on the 0-24 Roland-Morris Disability Questionnaire scale. The followup rate was $>90 \%$ for all outcomes. This research is considered capable of giving a good effect.

\section{CONCLUSIONS}

The main goal of low back pain treatments is to reduce pain in patients with acute and chronic low back pain. Based on the discussion can be concluded also that the noneffective treatment of infectious in treating pain in Low Back Pain (LBP) in the form of several ways that can be done in reducing pain through non-invasive treatment such as Acupunture, Massage, Spinal Manipulation, Yoga and Tai chi able to reduce pain LBP . From the results of the literature, the most effective method in terms of time and cost is spinal manipulation where the effect of reducing pain can be maintained for a long time and more applicable because without using tools. However, treatment combined with other treatments and performed on an ongoing basis will result in better outcomes. The need for effective LBP treatment to reduce pain is desperately needed by LBP patients, it is expected that the results of this lithographic study should be input to all parties in improving patient service with LBP.

\section{REFERENCES}

De Campos, T. (2017). Low Back Pain and Scatica in Over 16s: assesment and management NICE Guidline. $J$ Physiothe .

Hall, A. M., Maher, C. G., Lam, P., Ferreira, M., \& Latimer, J. (2011). Tai chi exercise for treatment of pain and disability in people with persistent low back pain: A randomized controlled trial. Arthritis Care and Research, 63(11), 15761583. https://doi.org/10.1002/acr.20594

Hasegawa, T. M., Baptista, A. S., de Souza, M. C., Yoshizumi, A. M., \& Natour, J. 
(2014). Acupuncture for acute non-specific low back pain: a randomised, controlled, double-blind, placebo trial. Acupuncture in Medicine : Journal of the British Medical Acupuncture Society, 32(2), 109-115. https://doi.org/10.1136/acupmed-2013-010333

Henschke, N., Maher, C., Refshauge, K., Herbert, R., Cumming, R., Blease, J., et al. (2009). prevelence of and screening for serious spinal pathology in patiens presenting to primary care with acute low back pain.

Lin, C. W. C., Haas, M., Maher, C. G., MacHado, L. A. C., \& Van Tulder, M. W. (2011). Cost-effectiveness of guideline-endorsed treatments for low back pain: A systematic review. European Spine Journal, 20(7), 1024-1038. https://doi.org/10.1007/s00586-010-1676-3

Michael Schneider, Mitchell Haas, Ronald Glick, Joel Stevans, G. L. (2015). A comparison of spinal manipulation methods and usual medical care for acute and sub-acute low back pain: a randomized clinical trial. Spine, 40(4), 209-217. https://doi.org/10.1097/BRS.0000000000000724.A

Qasem, A., McLean, R., Forciea, M., \& Wilth, T. (2017). Clinical Guidline Committe of the American Colllege of Physician. Non invasive treatment for acut, sub acut, and cronic low back pain: a clinical practice guidline from the American Colledge of Physician. Ann Intern Med. Epub .

Senna, M. K., \& MacHaly, S. A. (2011). Does maintained spinal manipulation therapy for chronic nonspecific low back pain result in better long-term outcome? Spine, 36(18), 1427-1437. https://doi.org/10.1097/BRS.0b013e3181f5dfe0

Stochkendahl, M., Kajer, P., Hartvigsen, J., Kongsted, A., Aeboe, J., Andersen, M., et al. (2017). National Clinical Guidline for non-surgical Treatment of Patiens with recent onset low back pain or lumbar radiculophaty. Eur Spine J , 1-16.

Williams, K., Ph, D., Abildso, C., Ph, D., Steinberg, L., Ph, D., ... Cooper, L. (2009). Evaluation of the effectiveness and efficacy of Iyengar Yoga Therapy on Chronic Low Back Pain. Spine, 34(1), 2066-2076. https://doi.org/10.1097/BRS.0b013e3181b315cc.Evaluation

Yoon, Y. S., Yu, K. P., Lee, K. J., Kwak, S. H., \& Kim, J. Y. (2012). Development and application of a newly designed massage instrument for deep cross-friction massage in chronic non-specific low back pain. Annals of Rehabilitation Medicine, 36(1), 55-65. https://doi.org/10.5535/arm.2012.36.1.55 
Cecep Eli Kosasih: A system Review: Non-Invasive Treatment to Reduce Low Back Pain

Zaringhalam, J., Manaheji, H., Rastqar, A., \& Zaringhalam, M. (2010). Reduction of chronic non-specific low back pain: A randomised controlled clinical trial on acupuncture and baclofen. Chinese Medicine, 5, 1-7. https://doi.org/10.1186/1749-8546-5-15 